\title{
Pengaruh Moral Wajib Pajak, Sikap Wajib Pajak dan Norma Subjektif terhadap Kepatuhan Pajak melalui Pemahaman Akuntansi
}

\author{
Ahmad Sani ${ }^{1}$, Azwansyah Habibie ${ }^{2}$ \\ ${ }^{1,2}$ Program studi Akuntansi, STIE Harapan Medan \\ ${ }^{1}$ saniahmad20152015@gmail.com, 2azwanhabibie@gmail.com
}

\begin{abstract}
Abstrak, prediktor kepatuhan pajak sampai saat ini menarik perhatian para peneliti di setiap negara. Namun penelitian di Kota Medan menguatkan prediksi tingkat kepatuhan pajak masih rendah. Meskipun tingkat pertumbuhan Usaha Mikro Kecil Menengah (UMKM) di Kota Medan semakin meningkat dari tahun ketahun, namun pertumbuhan tersebut tidak menunjukkan kenaikan tingkat kepatuhan pajak di Kota Medan. Tujuan dari penelitian ini adalah untuk memprediksi variabel moral wajib pajak, sikap wajib pajak, norma subjektif pada kepatuhan pajak melalui pemahaman akuntansi. Responden yang digunakan dalam penelitian ini adalah UMKM di Kota Medan. Penelitian survei menjadi desain penelitian ini dengan menggunakan kuesioner sebagai instrumen. Dua ratus UMKM berpartisipasi dalam penelitian ini. Data dianalisis menggunakan Partial Least Square (PLS) dengan menggunakan SmartPLS. Hasil penelitian menemukan bahwa terdapat pengaruh postif tetapi tidak signifikan pada Moral, Sikap, Norma Subjektif terhadap Kepatuhan Pajak. Terdapat Pengaruh postif dan signifikan pada Moral terhadap Pemahaman Akuntansi. Terdapat pengaruh negatif dan tidak signifikan pada Sikap terhadap Pemahaman Akuntansi. Terdapat pengaruh positif dan tidak signifikan pada Norma Subjektif terhadap Pemahaman Akuntansi. Pengaruh total effect dan indirect effect diketahui bahwa secara statistik berpengaruh positif dan signifikan Moral Wajib Pajak dan Norma Subjektif terhadap Kepatuhan Pajak melalui Pemahamahan Akuntansi. Pengaruh total effect dan indirect effect diketahui bahwa secara statistik berpengaruh negatif dan signifikan Sikap Wajib Pajak terhadap Kepatuhan Pajak melalui Pemahaman Akuntansi.
\end{abstract}

Kata kunci: Moral, sikap wajib pajak, norma subjektif, pemahaman, kepatuhan pajak

\section{Pendahuluan}

Pajak merupakan salah satu sumber penerimaan negara terbesar dalam APBN. Berdasarkan data dari Badan Pusat Statistik per 22 Maret 2016 penerimaan negara dari Penerimaan Dalam Negeri pada sektor Penerimaan Pajak mencapai 84,7\% yakni Rp.1.565.784,1 (Milyar Rupiah). Sementara dari sektor Penerimaan Bukan Pajak mencapai 15,2\% yakni Rp.280.291,4 (Milyar Rupiah) dan Penerimaan Hibah mencapai 0,11\% yakni Rp.2.031,8 (Milyar Rupiah). Berdasarkan data tersebut dapat dikatakan bahwa hampir seluruh penerimaan negara berasal dari Penerimaan Pajak. Sehingga sampai saat ini pajak merupakan salah satu sumber penerimaan negara yang dinilai efektif yang memiliki peranan yang strategis. Terlebih pajak diharapkan sangat berperan dalam meningkatkan kemakmuran dan kesejahteraan bangsa. 
Berarti peranan pajak sangat berpengaruh terhadap percepatan laju pertumbuhan di Indonesia oleh karena itu perlu ditingkatkan secara optimal.

Akar permasalahan dalam perpajakan di Indonesia adalah bagaimana pajak tersebut dapat dikelola secara optimal sementara pemungutan pajak sangat bergantung kepada peran wajib pajak. Berdasarkan kenyataan sampai saat ini sebagian masyarakat enggan menjadi wajib pajak, sedangkan yang telah terdaftar sebagai wajib pajak masih banyak yang tidak mau melaporkan pajaknya apalagi untuk membayar pajak. Mulai dari wajib pajak kecil hingga sampai kepada wajib pajak besar. Berdasarkan informasi dari Dirjen Pajak hingga saat ini masih terdapat 129 juta masyarakat kelas menengah ke atas di Indonesia yang belum memiliki Nomor Pokok Wajib Pajak (NPWP) (https://pemeriksaanpajak.com, 10 Maret 2016). Oleh karena itu pemerintah saat ini harus lebih meningkatkan upaya untuk dapat menumbuhkan kepercayaan masyarakat terhadap pemerintah.

Akar permasalahan pajak lainnya yang dihadapi pemerintah diantaranya adalah kontribusi penerimaan pajak selama ini sebagian besar berasal dari wajib pajak besar sebagaimana data yang berhasil diperoleh yang bersumber dari Laporan Penerimaan Pajak DJPb, 5 Januari 2015 (http : // kigedemenoreh. blogspot.co.id) penerimaan pajak yang berasal dari PPh Pasal 25/29 Badan mencapai Rp.149.280.83 (Milyar Rupiah) dan penerimaan pajak yang berasal dari PPh Pasal 25/29 Orang Pribadi per 31 Desember 2014 mencapai Rp.4.724.82 (Milyar Rupiah). Sementara perkonomian Indonesia sebagian besar didominasi oleh kegiatan usaha yang berbasis pada Usaha Mikro Kecil Menengah (UMKM) yang memiliki potensi yang besar dalam pemungutan pajak. Potensi pajak bagi UMKM ditunjukkan oleh dominasi sektor UMKM dalam perekonomian nasional. Berdasarkan data dari Kementerian Koperasi dan UKM tahun 2012, jumlah UMKM mencapai 99\% dari jumlah unit usaha di Indonesia dan menyumbang 55,68\% PDB di Indonesia dengan potensi pajak sektor UMKM mencapai Rp30 triliun. Namun penyerapan dari Juli 2013 sampai 2014 hanya menyerap sekitar Rp2 triliun atau hanya 7\% dari total potensi pajak (http://www.neraca.co.id ). Dengan demikian pemerintah kehilangan pajak potensial yang bersumber dari UMKM. Posisi penting juga ditunjukkan oleh UMKM dalam membangun perekonomian negara dibuktikan dengan UMKM mampu menyerap 99,9 persen tenaga kerja di Indonesia dan berkontribusi terhadap PDB Indonesia sebesar 59 persen (http://ksp.go.id). UMKM juga terbukti mampu bertahan ketika terjadi krisis yang melanda Indonesia pada tahun 1998 dibandingkan dengan perusahaan besar karena UMKM tidak tergantung pada modal yang besar, atau pinjaman dari luar negeri dalam kurs dollar yang berpotensi mengalami imbas krisis (www.kemendag.go.id). Berdasarkan data yang bersumber dari Dinas Koperasi Usaha Mikro dan Menengah Kota Medan jumlah UMKM yang ada di Kota Medan sampai akhir tahun 2015 yang terdata mencapai 1.227 UMKM. Data ini menunjukkan angka yang sangat potensial untuk penerimaan pajak.

Untuk membuktikan permasalahan telah dilakukan survey awal kepada UMKM yang ada di Kota Medan sebagai responden dengan lokasi yang diambil secara acak. Kuesioner telah dibagikan kepada 200 responden. Berdasarkan survey awal dapat diprediksi bahwa tingkat kepatuhan pajak UMKM di Kota Medan dipengaruhi oleh banyak faktor, dalam hal ini sikap wajib pajak, moral wajib pajak khususnya UMKM berkaitan dengan pemahaman akuntansi yang dapat menjadi fenomena yang layak untuk diteliti. Walaupun berbagai kebijakan telah dilakukan pemerintah dalam mengelola sektor perpajakan, pajak dalam pemungutannya masih 
mengalami berbagai kendala dan hambatan terutama berasal dari para wajib pajak itu sendiri.

Berdasarkan survey di lapangan hampir semua UMKM di Kota Medan kesulitan di dalam mengisi, melapor dan membayarkan pajak terutangnya dengan benar dan tepat waktu. Sementara kepatuhan dalam perpajakan berkaitan dengan mengisi, melapor dan membayarkan pajak terutangnya dengan benar dan tepat waktu (Saepudin, 2012). Kepatuhan dalam membayar pajak akan tercapai apabila wajib pajak telah memahami akuntansi yang berkaitan dengan perhitungan pajak dan ketentuan umum mengenai kewajiban dan sanksi yang akan diperoleh jika tidak membayar pajak. Penelitian ini memprediksi bahwa moralitas wajib pajak, sikap wajib pajak dan norma subjektif berpengaruh terhadap kepatuhan pajak apabila wajib pajak memiliki pemahaman akuntansi. Penelitian ini mencoba mengupas kembali penelitian yang telah dilakukan sebelumnya dengan menambahkan pemahaman akuntansi sebagai variabel intervening. Sampel dalam penelitian ini difokuskan pada kepatuhan pajak pada UMKM di Kota Medan.

\section{Tinjauan}

Kepatuhan pajak sejauh mana wajib pajak telah mematuhi (atau gagal mematuhi) dengan peraturan perpajakan negaranya, misalnya dengan melaporkan penghasilan, mengajukan pengembalian, dan membayar pajak jatuh tempo pada waktu yang tepat (www.moneycontrol.com). Ada beberapa teori yang melandasi kepatuhan pajak menurut Hardika (2006) dalam Salman dan Farid (2008). Prospect Theory, orang-orang menghargai keuntungan dan kerugian yang berbeda dan, dengan demikian, akan mendasarkan keputusan pada keuntungan yang dirasakan daripada kerugian yang dirasakan (www.investopedia.com). Deterrence Theory, menggambarkan suatu model yang memperhitungkan biaya dan manfaat potensial yang akan diperoleh dari suatu tindakan yang dipilih. Cognitive Structures, sikap patuh terhadap pajak mempengaruhi perilaku wajib pajak melalui niat dan niat akhirnya mempengaruhi perilaku membayar pajak (Salman dan Farid, 2008). Agency Theory terkait dengan situasi dimana seorang individu yang bekerja sebagai agen bagi individu lain (principle) dan memberikan hasil kepada principle-nya. Atribution Theory, persepsi seseorang untuk membuat penilaian mengenai orang lain sangat dipengaruhi oleh kondisi internal maupun eksternal orang tersebut (Jatmiko, 2006).

Moral pajak, dipandang sebagai motivasi intrinsik untuk membayar pajak, Menurut Torgler (2007) moral pajak adalah motivasi intrinsik untuk mematuhi dan membayar pajak sehingga berkontribusi secara sukarela pada penyediaan barangbarang publik. Moral pajak merupakan determinan kunci yang dapat menjelaskan mengapa orang jujur dalam masalah perpajakan (Cahyonowati, 2011). Teori yang dianggap erat kaitannya dengan moral wajib pajak adalah theory of moral reasoning. Theory of moral reasoning dalam kontek kepatuhan pajak menyatakan bahwa keputusan moral terutama dipengaruhi oleh perlakuaan terhadap sanksi pada tingkat moral reasoning yang rendah, pengharapan akan adanya keadilan pada tingkat moderat, dan issue keadilan pada tingkat yang tertinggi. Wajib pajak yang lebih menggunakan moral dalam pengambilan keputusan pembayaran pajak akan lebih patuh dibandingkan dengan wajib pajak lainya. Wajib pajak dengan tingkat moral 
yang sama tetapi memiliki persepsi yang berbeda akan memiliki reaksi yang berbeda terhadap kepatuhan pajak (Jayanto, 2011).

Sikap merupakan sebuah evaluasi kepercayaan atas perasaan positif maupun negatif dari seseorang jika harus melakukan perilaku yang akan ditentukan. Jogiyanto (2007) mendefinisikan sikap sebagai jumlah dari afeksi (perasaan) yang dirasakan seseorang untuk menerima atau menolak suatu obyek atau perilaku dan diukur dengan menempatkan individu pada skala evaluatif dua kutub, misalnya baik atau buruk, setuju atau menolak, dan lain sebagainya. Hubungan antara sikap wajib pajak dengan kepatuhan wajib pajak sangat erat kaitannya dengan teori ekuitas (equity theory) (Salman dan Farid, 2008). Equity theory adalah gagasan bahwa semua orang ingin diperlakukan secara adil dan dengan demikian membandingkan kontribusi dan imbalan mereka sendiri dengan kontribusi dan imbalan rekan kerja mereka, untuk menentukan apakah mereka sudah diperlakukan secara adil (http://kamusbisnis.com).

Norma subjektif adalah satu jenis tertentu dari norma yang belum mendapat banyak perhatian di bidang kepatuhan pajak, yang didefinisikan sebagai norma yang dimiliki oleh individu yang berasal dari rujukan orang lain (teman, keluarga, rekan kerja dekat) tentang perilaku (yaitu, dalam hal ini kasus, apakah mereka setuju atau membiarkan penggelapan pajak). Norma subjektif tidak terlepas dari Theory of Planned Behavior (TPB), yang menghubungkan keyakinan dengan perilaku. Bila dikaitkan dengan UMKM teori ini sangat sesuai digunakan untukmenjelaskan berbagai perilaku di dalam kewirausahaan. TPB cocok untuk kewirausahaan karena menjelaskan perilaku apa pun yang memerlukan perencanaan (Onu dan Oats, 2014).

Pemahaman adalah bagaimana seorang mempertahankan, membedakan, menduga, menerangkan, memperluas, menyimpulkan, menggeneralisasikan, memberikan contoh, menuliskan kembali, dan memperkirakan (Arikunto, 2009). Akuntansi dapat diartikan sebagai sistem informasi yang menyediakan laporan untuk para pemangku kepentingan atau pihak-pihak yang memerlukannya mengenai aktivitas ekonomi dan kondisi perusahaan (Warren et. al., 2014; Horngren, 2006). Dalam kaitannya dengan pajak penghasilan semua badan usaha dan perorangan diwajibkan menyelenggarakan laporan yang cukup memadai agar dapat menyusun surat pemberitahuan pajaknya secara teliti. Dengan demikian sesederhana apapun pemahaman atas aspek pajak penghasilan hampir tidak mungkin tanpa memiliki pengetahuan mengenai konsep akuntansi.

Hasil penelitian Salman dan Farid (2008) menemukan bahwa moral wajib pajak tidak berpengaruh secara signifikan terhadap kepatuhan wajib pajak. Sedangkan sikap wajib pajak berpengaruh secara signifikan terhadap kepatuhan wajib pajak. Hasil penelitian Saefudin (2012) menunjukkan bahwa pemahaman akuntansi, pemahaman ketentuan perpajakan dan transparansi dalam pajak secara simultan berpengaruh signifikan terhadap kepatuhan wajib pajak badan. Hasil penelitian Ernawati dan Wijaya (2011) menyimpulkan bahwa Pemahaman Akuntansi Pajak mempunyai pengaruh positif dan signifikan terhadap Kepatuhan Wajib Pajak Badan. Penelitian Sumianto dan Kurniawan (2015) menemukan bahwa pemahaman akuntansi dan pemahaman ketentuan pajak berpengaruh positif dalam meningkatkan kepatuhan membayar pajak. Hasil penelitian Tusubira dan Nkote (2013) menemukan bahwa norma-norma sosial dan moral wajib pajak secara signifikan berkorelasi positif dengan kepatuhan pajak. Hasil penelitian Bobek et al., (2013) menunjukkan bahwa norma-norma sosial memiliki pengaruh signifikan 
langsung serta tidak langsung terhadap perilaku kepatuhan pajak. Hasil penelitian Nkwe (2013) menyimpulkan bahwa sikap wajib pajak berpengaruh terhadap perilaku kepatuhan pajak.

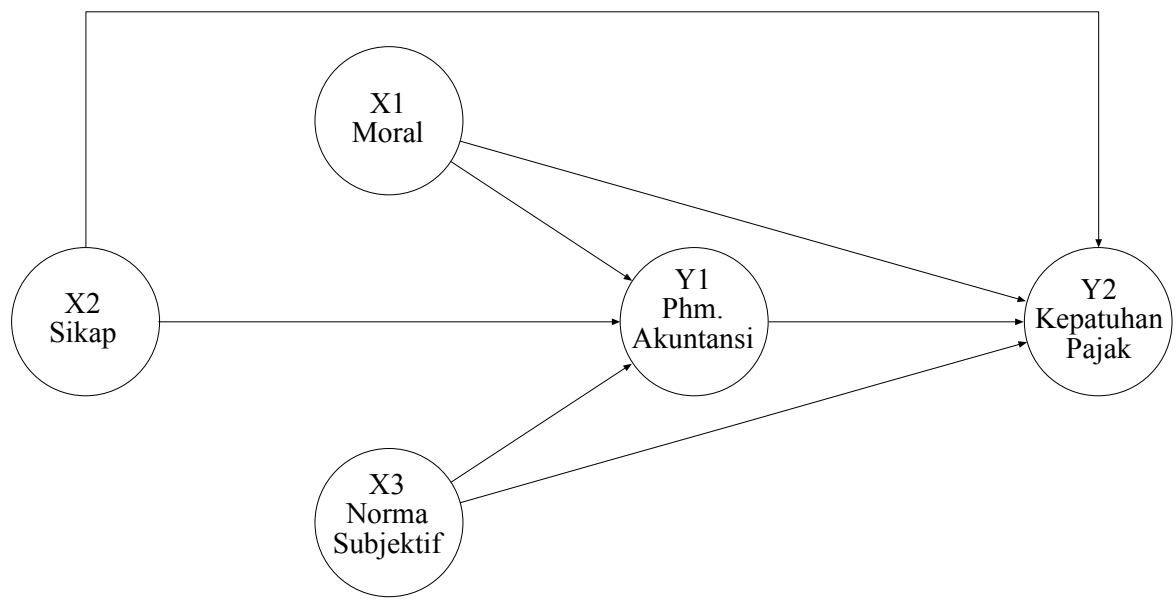

Gambar 1: Model penelitian

\section{Metode}

Menurut jenisnya penelitian ini merupakan penelitian eksplanatif (explanatory research) pada tingkat asosiatif kausal dengan teknik survei untuk menganalisis hubungan kausalitas antara moral wajib pajak, sikap wajib pajak dan norma subjektif dengan kepatuhan wajib pajak melaluli pemahaman akuntansi. Penelitian asosiatif kausal adalah penelitian yang mempunyai tujuan untuk mengetahui hubungan antara dua variabel atau lebih (Sugiyono, 2010) dalam hal ini hubungan yang terbentuk adalah hubungan kausal yang bersifat sebab akibat. Artinya ada variabel yang memengaruhi (variabel bebas atau independent, atau variabel eksogen), dan ada variabel yang dipengaruhi (variabel terikat atau dependent, atau variabel endogen) (Wiyono, 2012).

Penelitian ini menggunakan metode penelitian kuantitatif dengan data primer yang bersumber dari data kualitatif yang diperoleh dari hasil survei dengan kuesioner yang kemudian diolah menjadi data kuantitatif. Sumber data primer pada penelitian ini diperoleh langsung dari UMKM yang ada di Kota Medan. Kuesioner dibagikan kepada UMKM yang menjadi responden terpilih dalam penelitian ini.

Penelitian ini dilakukan pada UMKM yang ada di Kota Medan Sumatera Utara. Bukti kemampuan bertahan hidup dalam terpaan krisis ekonomi dan tingkat pertumbuhan UMKM di Kota Medan yang sangat pesat sehingga menjadi perhatian dalam penelitian ini. Pertumbuhan UMKM di Kota Medan dipandang sebagai salah satu sumber penerimaan negara yang dapat dianggap sebagai pajak yang potensial yang pantas digali.

Populasi dalam penelitian ini adalah seluruh UMKM yang ada di Kota Medan. Jumlah populasi dalam penelitian ini sebanyak 200 UMKM yang dipilih. Guna efisiensi waktu dan biaya, maka tidak semua UMKM dapat dijadikan objek dalam penelitian ini. Oleh karena itu dilakukanlah pengambilan sampel. Pengambilan sampel dalam penelitian ini dilakukan dengan menggunakan metode 
simple random sampling. Sampelnya adalah orang-orang yang ditemui oleh peneliti secara acak. Sugiyono (2010) menyatakan bahwa sampel adalah bagian dari jumlah dan karakteristik yang dimiliki oleh populasi tersebut. Ukuran sampel yang digunakan dalam penelitian ini ditentukan menurut ketentuan Slovin (Sanusi, 2011):

$$
\mathrm{n}=\frac{\mathrm{N}}{1+\mathrm{N}(\mathrm{e})^{2}}
$$

Berdasarkan data yang diperoleh dari survei lapangan tahun 2016, tercatat sebanyak 200 UMKM. Oleh karena itu, jumlah sampel untuk penelitian dengan margin of error sebesar $10 \%$ adalah:

$$
\begin{aligned}
& \mathrm{n}=\frac{200}{1+200(0.1)^{2}} \\
& \mathrm{n}=66.66, \text { dibulatkan menjadi } 67
\end{aligned}
$$

Dalam penelitian ini penulis memperoleh data yang diperlukan dengan menggunakan cara sebagai berikut:

1. Pengumpulan data primer dilakukan dengan metode survey menggunakan media angket (kuesioner). Sejumlah pertanyaan akan diajukan kepada responden dan kemudian responden diminta menjawab sesuai dengan pendapat mereka. Untuk mengukur pendapat responden, digunakan skala Likert dengan perincian sebagai berikut. Kategori Sangat Setuju (SS) diberi skor 5; Kategori Setuju (ST) diberi skor 4; Kategori Netral (N) diberi skor 3; Kategori Tidak Setuju (TS) diberi skor 2; Kategori Sangat Tidak Setuju (STS) diberi skor 1 (Sugiyono, 2010).

2. Tinjauan kepustakaan (library research), metode ini dilakukan dengan mempelajari teori-teori dan konsep-konsep yang sehubungan dengan masalah yang diteliti pada buku-buku, makalah, dan jurnal guna memperoleh landasan teoritis yang memadai untuk melakukan pembahasan.

3. Mengakses website dan situs-situs yang menyediakan informasi sehubungan dengan masalah dalam penelitian dan teori yang mendukung atas penelitian yang dilakukan.

Variabel eksogen dalam penelitian ini adalah moral wajib pajak $\left(\mathrm{X}_{1}\right)$, sikap wajib pajak $\left(\mathrm{X}_{2}\right)$ dan norma subjektif $\left(\mathrm{X}_{3}\right)$. Pemahaman akuntansi $\left(\mathrm{Y}_{1}\right)$ sebagai variabel intervening. Sedangkan variabel endogen adalah kepatuhan wajib pajak $\left(\mathrm{Y}_{2}\right)$. Semua variabel dalam penelitian ini diukur dengan tingkatan skala pengukuran skala ordinal, dan skala penelitian skala Likert's yaitu responden diminta menjawab kuesioner yang jawabannya diberi scor 1 sampai dengan 5 .

Tabel 1. Definisi Operasional variabel

\begin{tabular}{|l|l|l|l|}
\hline No & Variabel & Indikator Pertanyaan & $\begin{array}{l}\text { Skala } \\
\text { ukur }\end{array}$ \\
\hline 1. & Moral & 1. Melanggar etika & Likert/ \\
& & 2. & Perasaan bersalah \\
& & 3. & Prinsip hidup \\
& 4. & Melanggar prosedur & \\
\hline
\end{tabular}




\begin{tabular}{|c|c|c|c|}
\hline 2. & Sikap & $\begin{array}{l}\text { 1. Keinginan membayar pajak lebih kecil dari seharusnya } \\
\text { 2. Perasaan pemanfaatan pajak yang tidak transparan } \\
\text { 3. Perasaaan dirugikan oleh sistem perpajakan } \\
\text { 4. Biaya suap kepada petugas pajak lebih kecil dibandingkan } \\
\text { pajak yang bisa dihemat } \\
\text { 5. Sulitnya peraturan perpajakan } \\
\text { 6. Frekuensi perubahan peraturan } \\
\text { 7. Besar dan banyaknya jenis tarif pajak }\end{array}$ & $\begin{array}{l}\text { Likert/ } \\
\text { ordinal }\end{array}$ \\
\hline 3. & $\begin{array}{l}\text { Norma } \\
\text { Subjektif }\end{array}$ & $\begin{array}{l}\text { 1. Keluarga saya pernah mendorong untuk mematuhi ketentuan } \\
\text { perpajakan. } \\
\text { 2. Teman saya pernah mendorong untuk mematuhi ketentuan } \\
\text { perpajakan. } \\
\text { 3. Konsultan pajak pernah membujuk saya untuk mematuhi } \\
\text { ketentuan perpajakan. } \\
\text { 4. Petugas pajak pernah membujuk saya untuk mematuhi } \\
\text { ketentuan perpajakan. } \\
\text { 5. Media cetak / media elektronik pernah memengaruhi saya } \\
\text { untuk mematuhi ketentuan perpajakan. }\end{array}$ & $\begin{array}{l}\text { Likert/ } \\
\text { ordinal }\end{array}$ \\
\hline 4. & $\begin{array}{l}\text { Pemahaman } \\
\text { Akuntansi }\end{array}$ & $\begin{array}{l}\text { 1. Apakah Bapak/lbu selalu mencatat transaksitransaksi yang } \\
\text { terjadi di perusahaan berdasarkan urutan kejadiannya? } \\
\text { 2. Apakah di perusahaan Bapak/lbu, jurnal yang disusun } \\
\text { berdasarkan transaksi yang terjadi selalu seimbang antara sisi } \\
\text { debit dan sisi kredit? } \\
\text { 3. Apakah Bapak/lbu selalu mengelompokkan transaksi-transaksi } \\
\text { yang sudah dicatat menurut kelompok akun yang ada, yaitu } \\
\text { kelompok akun, akun kewajiban, akun ekuitas, akun } \\
\text { pendapatan dan akun beban? } \\
\text { 4. Apakah pelaksanaan dalam pengelompokkan data keuangan } \\
\text { di perusahaan Bapak//bu berjalan lancar? } \\
\text { 5. Apakah tahap pengikhtisaran data keuangan di perusahaan } \\
\text { Bapak/lbu terdiri dari pembuatan neraca saldo, neraca lajur } \\
\text { dan jurnal penyesuaian? } \\
\text { 6. Apakah Bapak/lbu memahami bahwa neraca saldo } \\
\text { merupakan titik awal yang baik untuk penyusunan laporan } \\
\text { keuangan? } \\
\text { 7. Apakah Bapak/lbu setuju bahwa laporan keuangan harus } \\
\text { disusun secara sistematis untuk dapat dipahami dan dapat } \\
\text { diperbandingkan serta disajikan secara lengkap? } \\
\text { 8. Apakah Bapak/lbu memahami bahwa laporan labarugi } \\
\text { menunjukkan gambaran kinerja perusahaan selama satu } \\
\text { periode? } \\
\text { 9. Apakah dengan adanya hasil dari penafsiaran data keuangan } \\
\text { membantu Bapak/lbu dalam pengembangan usaha? } \\
\text { 10. Apakah Bapak/lbu memahami bahwa penafsiran data } \\
\text { keuangan merupakan membaca laporan keuangan yang } \\
\text { dihasilkan sehingga dapat diketahui kinerja dan posisi } \\
\text { keuangan untuk perusahaan? }\end{array}$ & $\begin{array}{l}\text { Likert/ } \\
\text { ordinal }\end{array}$ \\
\hline 5. & $\begin{array}{l}\text { Kepatuhan } \\
\text { Wajib Pajak }\end{array}$ & $\begin{array}{l}\text { 1. Apakah Bapak/lbu setuju bahwa setiap wajib pajak yang } \\
\text { memiliki penghasilan wajib mendaftarkan diri untuk } \\
\text { memperoleh NPWP? } \\
\text { 2. Apakah Bapak/lbu setuju bahwa sebagai wajib pajak harus } \\
\text { mempunyai NPWP yang digunakan sebagai identitas wajib } \\
\text { pajak? }\end{array}$ & $\begin{array}{l}\text { Likert/ } \\
\text { ordinal }\end{array}$ \\
\hline
\end{tabular}




\begin{tabular}{|l|l|l|}
\hline & $\begin{array}{l}\text { 3. Apakah Bapak/lbu melaporkan sendiri SPT tahunan ke Kantor } \\
\text { Pelayanan Pajak (KPP)? } \\
\text { 4. Apakah Bapak/lbu mengisi dengan benar semua bagian } \\
\text { formulir SPT tahunan? }\end{array}$ \\
5. Apakah jumlah pajak terutang yang disampaikan/dibayarkan \\
Bapak/lbu sesuai dengan ketentuan perpajakan dan sesuai \\
dengan kenyataan pembukuannya (melaporkan sebenarnya)? \\
6. Apakah Bapak/lbu membayar pajak terutang perusahaan \\
selalu tepat waktu? \\
7. Apakah tindakan Bapak/lbu sebagai wajib pajak terhadap \\
tunggakan pajak membayar sebesar tunggakannya? \\
8. Apa Bapak/lbu selalu segera melunasi tunggakan pajak \\
apabila memiliki tunggakan?
\end{tabular}

\section{Teknik Analisis Data}

\section{Statistik Deskriptif}

Statistik deskriptif digunakan untuk menganalisa data dengan cara mendeskripsikan atau menggambarkan data sampel yang digunakan dalam penelitian. Penelitian ini mencoba mendeskripsikan atau menggambarkan data sampel berdasarkan nilai minimum, nilai maksimum, nilai rata-rata (mean), nilai tengah (median), simpangan baku (standard deviation) dan range.

\section{Uji Normalitas Data}

Meskipun uji normalitas data dapat diabaikan dalam metode $P L S$, tetapi uji normalitas data tetap kami lakukan dengan menggunakan metode Regresi Linear menggunakan aplikasi SPSS untuk memberi bukti dan keyakinan bahwa data dalam penelitian ini terdistribusi secara normal dan layak digunakan. Penelitian ini menggunakan uji statistik non-parametrik Kolmogorov-Smirnov yang menggunakan fungsi distribusi kumulatif dalam uji normalitas. Nilai residual terstandarisasi berdistribusi normal jika $\mathrm{K}$ hitung $<\mathrm{K}$ tabel atau nilai Sig. (2-tailed) $>$ alpha $(0,05)$ yang menunjukkan nilai residual terstandarisasi dinyatakan menyebar secara normal.

\section{Uji Hipotesis}

Partial Least Square (PLS)

Teknik analisis data dalam penelitian ini adalah Structural Equation Modeling (SEM) berbasis varian dengan alternatif Partial Least Square (PLS) menggunakan software SmartPLS. Secara umum teknik analisis PLS digunakan adalah karena : (1) mampu mengukur lebih dari satu variabel dependen/endogen; (2) mampu mengukur konstruk dengan variabel indikator atau variabel manifest; (3) mampu mengukur konstruk dengan indikator formatif sekaligus indikator refleksif (walaupun dalam penelitian ini tidak menggunakan indikator formatif); (4) tidak didasarkan pada banyak asumsi; (5) mampu mengukur sampel dalam jumlah yang relatif kecil; (6) dapat mengatasi adanya missing values; (7) dapat mengatasi adanya masalah normalitas data; (8) dapat mengatasi adanya multikolinieritas, sehingga alat analisis ini cocok digunakan dalam penelitian ini. Metode PLS dapat digunakan baik untuk melakukan konfirmasi teori (theoritical testing) maupun merekomendasikan hubungan yang belum ada teorinya (exploratory). 


\section{Uji Model}

Uji model pada metode PLS dilakukan melalui outer model yaitu pengujian yang dilakukan pada indikator dan uji inner model yaitu perlakuan pengujian atas hipotesis penelitian.

Pengujian Hipotesis (Resampling Bootstraping)

1. $\mathrm{H}_{1}$ diterima apabila: (a) Uji-t: t-hitung $>\mathrm{t}$-tabel, (b) Path coefficient (koefisien parameter jalur), menunjukkan sifat korelasi/hubungan antar variabel laten baik positif maupun negatif. Variabel-variabel Moral, Sikap, Norma Subjektif dan Pemahaman Akuntansi berpengaruh positif dan signifikan terhadap Kepatuhan Pajak.

2. $\mathrm{H}_{2}$ diterima apabila: (a) Uji-t: t-hitung $>\mathrm{t}$-tabel, (b) Path coefficient (koefisien parameter jalur), menunjukkan sifat korelasi/hubungan antar variabel laten baik positif maupun negatif. Variabel-variabel Moral, Sikap dan Norma Subjektif berpengaruh positif dan signifikan terhadap Pemahaman Akuntansi.

3. $\mathrm{H}_{3}$ diterima apabila: (a) Uji-t: t-hitung $>\mathrm{t}$-tabel, (b) Path coefficient (koefisien parameter jalur), menunjukkan sifat korelasi/hubungan antar variabel laten (positif/negatif). Variabel-variabel Moral, Sikap dan Norma Subjektif berpengaruh positif dan signifikan terhadap Kepatuhan Pajak melalui Pemahaman Akuntansi.

\section{Hasil penelitian}

Responden dalam penelitian dapat dilihat melalui usia, jenis kelamin, dan pendidikan terakhir, dan pernah/tidaknya mengisi SPT Pajak. Penelitian memiliki 67 sampel dan telah dilakukan penyebaran 71 kuesioner kepada para pedagang atau pelaku UMKM di 8 pasar yang ada di Kota Medan.

Berdasarkan pengelompokkan usia, responden yang mendominasi berusia antara 41-50 tahun hal ini diprediksi bahwa dengan usia 41-50 tahun dan 51-60 menunjukkan para pedagang di pasar-pasar di Kota Medan masih didominasi para pedagang yang sudah berkecimpung lama di UMKM, ini dibuktikan dengan lamanya mereka melakukan usaha mulai 3-30 tahun dan 6-28 tahun. Pengelompokkan responden berdasarkan jenis kelamin dari 71 yang terpilih, responden dengan jenis kelamin laki-laki sebanyak 41 orang dengan persentase $58 \%$ mendominasi UMKM di Kota Medan. Sementara responden perempuan hanya berjumlah 30 orang dengan tingkat persentase 42\%. Berdasarkan survey hampir seluruh pedagang atau pelaku UMKM di Kota Medan merupakan lulusan SMA sederajat dengan jumlah 51 orang dari 71 responden dengan tingkat persentase $72 \%$, hal ini menunjukkan rata-rata lulusan SMA di Kota Medan tidak berkeinginan atau tidak mampu melanjutkan sekolah ke perguruan tinggi tetapi lebih memilih berdagang. Responden yang merupakan lulusan SD dan D3 masing-masing 1 orang (1\%), SMP 13 orang (18\%), dan S1 hanya 5 orang (7\%). Berdasarkan survey dapat juga dilihat informasi bahwa hampir tidak ada lagi pedagang yang hanya lulusan SD tetapi sebagian lagi masih ada yang hanya sampai lulusan SMP. Berdasarkan survey memberikan informasi bahwa terdapat 710 jawaban yang diperoleh dari 71 responden dikali 10 indikator pertanyaan. Dari survey diperoleh informasi bahwa sebagian besar pelaku usaha UMKM di pasar-pasar di Kota Medan diprediksi tidak mendapat dorongan dan saran yang dapat dipertimbangkan untuk patuh terhadap 
pajak. Berdasarkan survey diperoleh informasi bahwa terdapat 710 jawaban yang diperoleh dari 71 responden dikali 10 indikator pertanyaan. Dari survey diperoleh informasi bahwa sebagian besar pelaku usaha UMKM di pasar-pasar di Kota Medan diprediksi tidak memahami akuntansi dan tidak mau menerapkan akuntansi dalam menjalankan usahanya. Berdasarkan survey memberikan informasi bahwa terdapat 568 jawaban yang diperoleh dari 71 responden dikali 8 indikator pertanyaan. Dari survey diperoleh informasi bahwa sebagian besar pelaku usaha UMKM di pasarpasar di Kota Medan diprediksi tidak patuh terhadap pajak.

\section{Analisis Data}

Statistic Deskriptive

Statistics descriptive atas variabel eksogen Moral Wajib Pajak (X1) dan indikator-indikator (sub variabel) yang dipengaruhinya dapat diperoleh informasi bahwa responden menganggap tidak ada norma yang dapat menghalangi responden untuk tidak patuh terhadap pajak, kecuali responden menganggap bahwa tidak patuh terhadap pajak hanya melanggar prosedur. Statistics descriptive atas variabel eksogen Sikap Wajib Pajak (X2) dan indikator-indikator (sub variabel) yang dipengaruhinya. Berdasarkan hasil statistik deskriptif dapat diperoleh informasi bahwa responden memiliki pandangan yang negatif terhadap pajak. Statistics descriptive atas variabel eksogen Norma Subjektif (X3) dan indikator-indikator (sub variabel) yang dipengaruhinya dapat diperoleh informasi bahwa responden dalam memenuhi kewajiban perpajakannya tidak didorong oleh siapapun dan tidak mempertimbangkan saran dari siapapun secara pribadi dalam rangka memenuhi kewajiban perpajakannya. Statistics Descriptive atas variabel endogen Pemahaman Akuntansi (Y1) dan indikator-indikator (sub variabel) yang dipengaruhinya dapat diperoleh informasi bahwa responden tidak menerapkan dengan baik bahkan tidak mampu maupun tidak mau menerapkan akuntansi dalam menjalankan usahanya walaupun responden menyadari bahwa akuntansi sangat baik untuk diterapkan dalam usaha karena akuntansi menunjukkan gambaran kinerja dan dapat memberikan laporan posisi keuangan untuk usaha mereka. Statistics Descriptive atas variabel endogen Kepatuhan Wajib Pajak (Y2) dan indikator-indikator (sub variabel) yang dipengaruhinya dapat diperoleh informasi bahwa responden tidak ada yang setuju dengan pertanyaan yang mendukung kepatuhan terhadap kewajiban perpajakan, kecuali responden setuju bahwa sebagai wajib pajak harus mempunyai NPWP yang digunakan sebagai identitas wajib pajak.

\section{Uji Normalitas}

Hasil pengujian menunjukkan bahwa seluruh variabel penelitian terdistribusi dengan normal. Hal ini dibuktikan dengan uji variabel-variabel eksogen terhadap variabel endogen Y1 nilai Sig. (2-tailed) 0,584 $>0,05$ demikian juga dengan nilai Absolute dan Kolmogorov-Smirnov Z masing-masing 0,092 dan 0,776 >0,05. Uji variabel-variabel eksogen dan endogen Y1 terhadap variabel endogen Y2 nilai Sig. (2-tailed) $0,123>0,05$ demikian juga dengan nilai Absolute dan KolmogorovSmirnov Z masing-masing 0,14 dan $1,181>0,05$. Hal ini berarti bahwa nilai residual terstandarisasi dinyatakan menyebar secara normal. 


\section{Uji Hipotesis}

\section{Uji Outer Model (Uji Indikator)}

Hasil pengujian outer model (Convergent Validity, Discriminant Validity, Uji AVE, Composite Reliability), tahap awal dari hasil Algorithm PLS, menunjukkan bahwa dari 39 indikator pertanyaan hanya 15 (loading factor $>0,70$ ) yang valid dan selebihnya ada 24 indikator yang dinyatakan tidak valid karena semua indikator memiliki nilai loading factor lebih kecil dari 0,70 (loading factor $<0,70$ ) terhadap variabel laten induknya dan AVE lebih kecil dari 0,50 dan variabel Sikap WP (X2) dianggap tidak reliabel. Berdasarkan hasil outer loading tersebut, maka 24 indikator yang dinyatakan tidak valid tersebut harus dikeluarkan dari model dan dilakukan pengujian ulang.

\section{Pengujian Ulang}

Oleh karena terdapat indikator dan konstruk yang memiliki nilai loading yang bernilai rendah sehingga variabel dianggap tidak valid dan tidak reliabel, maka perlu dilakukan pengujian ulang dengan mengeliminasi indikator-indikator yang tidak valid dan hanya melibatkan indikator-indikator yang valid. Hasil pengujian outer model (Convergent Validity, Discriminant Validity) tahap ke-dua hasil Algorithm PLS recalculate menunjukkan bahwa semua indikator pertanyaan dinyatakan valid karena semua indikator memiliki nilai loading factor lebih besar dari 0,70 (loading factor $>0,70)$ terhadap variabel laten induknya sehingga dapat dikatakan telah memenuhi syarat convergent validity dan discriminant validity. Nilai AVE (average variance extracted) dari semua variabel laten telah sesuai dengan yang direkomendasikan $>0.50$ mempunyai arti bahwa $50 \%$ atau lebih varian dari indikator dapat dijelaskan. Kesimpulan untuk kecocokan model untuk semua variabel laten dinilai sangat baik. Dengan demikian semua variabel laten sudah dapat menjelaskan masing-masing indikatornya. Dengan kata lain, semua variabel laten dapat mewakili masing-masing indikatornya. Berdasarkan hasil pengujian ulang reliabilitas, semua variabel laten (konstruk) dianggap reliabel atau hasilnya dapat dipercaya karena telah memenuhi syarat realibilitas dalam PLS dengan nilai Composite Reliability $>0.70$.

\section{Uji Inner Model (Uji Pengaruh/Uji Hipotesis)}

Pengujian inner model dapat dilakukan dengan melihat nilai koefisien determinasi $R$-square $\left(\mathrm{R}^{2}\right)$, koefisien parameter Stone-Geisser $Q$-square $\left(\mathrm{Q}^{2}\right)$ test dan uji-t. Berdasarkna Tabel 2. besarnya nilai $R$ square $\left(R^{2}\right)$ variabel intervening Pemahaman Akuntansi adalah 0,262281 atau dengan kata lain nilai koefisien determinasi untuk varibel intervening Pemahaman Akuntansi adalah sebesar $26,23 \%$. Angka tersebut mempunyai makna besarnya pengaruh variabel-variabel eksogen Moral, Sikap dan Norma Subjektif beserta variabel-variabel indikatornya secara gabungan terhadap variabel intervening Pemahaman Akuntansi beserta 4 variabel indikatornya. Dengan kata lain variabel intervening Pemahaman Akuntansi dapat dijelaskan atau diterangkan dengan menggunakan variabel-variabel eksogen Moral, Sikap dan Norma Subjektif secara bersama-sama sebesar 26,23\%, sedang sisanya $(1-0,262281)$, pengaruh sebesar 0,737719 atau $73,77 \%$ disebabkan oleh variabel-variabel lain diluar penelitian ini. Nilai $R$ square untuk variabel intervening 
Pemahaman Akuntansi dengan angka sebesar 0,262281 atau 26,23\% menunjukkan nilai tersebut termasuk dalam model kategori nilai $R$ square $\left(R^{2}\right)$ yang lemah.

Tabel 2. Hasil Evaluasi Model (Goodness-of-Fit-GoF)

\begin{tabular}{|c|c|c|c|c|c|}
\hline & R Square & communality & $\mathrm{H}^{2}$ & redundancy & $\mathrm{F}^{2}$ \\
\hline Akuntansi & 0,262281 & 0,736653 & 0,543687 & 0,170858 & 0,174877 \\
\hline Kepatuhan & 0,572878 & 0,763956 & 0,64196 & 0,407638 & 0,39916 \\
\hline Moral & & 0,83531 & 0,623448 & & 0,623448 \\
\hline Norma subjektif & & 1 & 0,780734 & & 0,780734 \\
\hline Sikap & & 1 & & & \\
\hline Average & 0,4175795 & 0,867184 & 0,647457 & 0,289248 & 0,49455475 \\
\hline \multicolumn{6}{|c|}{ GoF $=$ Vaverage $R 2 x$ average communality $=$} \\
\hline Note: $\mathrm{H} 2=\mathrm{CV}$ & onolity In & $F 2=C V-R$ & anoulo & innonhaus & 5) \\
\hline
\end{tabular}

Besarnya nilai $R$ square $\left(R^{2}\right)$ pada tabel 2 juga menunjukkan angka 0,572878 pada variabel endogen Kepatuhan Pajak. Angka tersebut mempunyai makna besarnya pengaruh variabel eksogen Moral, Sikap, Norma Subjektif dan Pemahaman Akuntansi beserta variabel-variabel indikatornya secara gabungan terhadap variabel endogen Kepatuhan Pajak beserta 5 variabel indikatornya. Angka 0,572878 atau $57,29 \%$ mempunyai makna sebagai besarnya pengaruh variabel eksogen Moral, Sikap dan Norma Subjektif dan variabel intervening Pemahaman Akuntansi beserta variabel-variabel indikatornya secara gabungan terhadap variabel endogen Kepatuhan Pajak beserta 5 variabel indikatornya. Dengan kata lain variabel endogen Kepatuhan Pajak dapat dijelaskan atau diterangkan dengan menggunakan variabelvariabel eksogen Moral, Sikap, Norma Subjektif dan variabel intervening Pemahaman Akuntansi sebesar 57,29\%, sedang sisanya (1 - 0,572878), pengaruh sebesar 0,427122 atau 42,71\%\% disebabkan oleh variabel-variabel lain diluar penelitian ini. Nilai $R$ square untuk variabel endogen Kepatuhan Pajak dengan angka sebesar 0,572878 menunjukkan nilai tersebut termasuk dalam model kategori nilai $R$ square $\left(R^{2}\right)$ yang moderate.

\section{Nilai $Q$-Square}

$Q$-Square $\left(Q^{2}\right)$ statistik mengukur relevansi prediksi model dengan mereproduksi nilai-nilai yang diamati oleh model itu sendiri. $Q$-Square lebih besar dari $0(Q$-Square $>0)$ berarti model memiliki relevansi prediktif; sedangkan statistik $Q$-Square kurang dari nol $(Q$-Square $<0)$ berarti bahwa model tidak memiliki relevansi prediktif. Nilai $Q$-Square dapat dilihat pada tabel redudancy yang diperoleh dari hasil evaluasi atau pengujian ulang dari algorithm SmartPLS 2.0 M3. Pada Tabel 2. dapat dilihat nilai redundancy dengan masing-masing bernilai sebesar $0,170858>0$ untuk variabel intervening Pemahaman Akuntansi dan sebesar $0,407638>0$ untuk variabel endogen Kepatuhan Pajak yang dapat diartikan bahwa model dalam penelitian ini memiliki nilai predictive relevance, dimana semakin mendekati 1 berarti model semakin kuat. Pada Tabel 2. dapat dilihat nilai communality dengan masing-masing bernilai sebesar 0,736653 $>0$ untuk variabel Pemahaman Akuntansi, 0,763956 > 0 untuk variabel Kepatuhan Pajak, 0,83531>0 untuk variabel Moral, dan masing-masing bernilai $1>0$ untuk variabel Norma Subjektif dan variabel Sikap yang dapat diartikan model dalam penelitian ini memiliki nilai predictive relevance, dimana angka nilai communality mulai dari 0,7 sampai dengan 1 menunjukkan model yang kuat. Tabel 2. menunjukkan bahwa hasil 
untuk model ini semua blok memiliki nilai $\mathrm{F}^{2}$ yang tinggi mulai dari 0,174877 sampai dengan 0,780734 dan $\mathrm{H}^{2}$ semua bernilai 0,543687 sampai dengan 0,780734. Semua nilai $\mathrm{F}^{2}$ dan $\mathrm{H}^{2}$ adalah positif (terus di atas ambang batas permukaan), yang berarti bahwa model memiliki relevansi prediktif yang dapat diterima.

\section{Analisis Pengaruh dengan nilai signifikansi t-value}

Quality Indexes

Untuk menilai fit model secara keseluruhan maka dilakukan Goodness-of-Fit $(G o F)$ (Tenenhaus et al., 2005). Gof adalah rata-rata geometris dari rata-rata komunalitas dan rata-rata $R^{2}$, yang merupakan indeks untuk memvalidasi model PLS secara global, seperti mencari kompromi antara kinerja model pengukuran dan model struktural, masing-masing. Untuk model ini indeks $G o F$ adalah 0,801487 sebagaimana ditampilkan pada Tabel 5.20.

GoF dengan nilai sebesar 0,801487 adalah nilai yang termasuk dalam kategori $G o F$ large (GoF yang besar/kuat) sebagaimana yang telah direkomendasikan (Latan dan Ghozali, 2012).

\section{Pengujian Hipotesis (Resampling Bootstraping)}

Pada sub-bab ini dilakukan pengujian efek mediasi menggunakan program SmartPLS 2.0 M3. Efek mediasi merupakan hubungan antara konstruk eksogen dan endogen melalui variabel penghubung atau antara. Dalam hal ini pengaruh variabel eksogen terhadap variabel endogen bisa secara langsung tetapi juga bisa melalui variabel penghubung atau mediasi. Evaluasi atau pengujian statistik yang digunakan adalah Degree of Freedom (DF) atau Derajat Kebebasan (DK) diperoleh T-tabel sebesar 1,6683 (significance level $=5 \%$ ). Tabel 3. memperlihatkan nilai koefisien parameter dan nilai T-statistik yang menunjukkan besarnya pengaruh dan signifikansi masing-masing variabel eksogen independen, variabel intervening dan pengaruhnya terhadap variabel endogen Kepatuhan Pajak.

Tabel 3. Direct Effect, Indirect Effect dan Total Effect

Direct Effect, Indirect Effect dan Total Effect

\begin{tabular}{lrrrrrr}
\hline & \multicolumn{2}{c}{ Direct Effect } & \multicolumn{2}{c}{ Indirect Effect } & \multicolumn{2}{c}{ Total Effect } \\
\cline { 2 - 7 } & Koef. & t-Statistik & Koef. & t-Statistik & Koef. & t-Statistik \\
\hline Moral -> Patuh & 0,09864 & 0,85308 & & & & \\
\hline Sikap -> Patuh & 0,019943 & 0,446884 & & & & \\
\hline Nor Sub -> Patuh & 0,106155 & 1,283393 & & & & \\
\hline Akun -> Patuh & 0,662969 & 6,782921 & & & & \\
\hline Moral -> Akun & 0,412159 & 4,555642 & & & & \\
\hline Sikap -> Akun & $-0,037714$ & 0,306161 & & & & \\
\hline Nor Sub -> Akun & 0,151362 & 1,446787 & & & & \\
\hline Moral -> Akun - -> Patuh & & 0,273249 & 30,900560 & 1,075128 & 11,338563 \\
\hline Sikap -> Akun --> Patuh & & $-0,025003$ & 2,076666 & 0,625255 & 7,089082 \\
\hline Nor Sub -> Akun --> Patuh & & 0,100348 & 9,813442 & 8,229708 & 8,229708 \\
\hline
\end{tabular}

Hipotesis pertama

Variabel-variabel Moral, Sikap dan Norma Subjektif berpengaruh positif dan signifikan terhadap Kepatuhan Pajak. Berdasarkan hasil bootstrapping path coefficient pada SmartPLS 2.0 M3 pada tabel 3. dapat dilihat bahwa variabel Moral, 
Sikap dan variabel Norma Subjektif memiliki nilai t-statistik di bawah 1,6683 ini dapat disimpulkan bahwa Moral, Sikap dan Norma Subjektif memiliki pengaruh yang tidak signifikan terhadap Kepatuhan Pajak. Masing-masing memiliki nilai koefisien parameter sebesar 0,09864, 0,019943, dan 0,106155 dengan nilai t-statistik $0,85308<1,6683$ dan $0,446884<1,6683$ dan $1,283393<1,6683$. Nilai tersebut memberi arti bahwa terdapat pengaruh tidak signifikan pada tingkat 5\% dengan nilai t-hitung $<$ dari t-tabel. Hal ini mengindikasikan terdapat pengaruh postif tetapi tidak signifikan pada Moral, Sikap, Norma Subjektif terhadap Kepatuhan Pajak. Sehingga dengan demikian maka hipotesis pertama ditolak.

Variabel-variabel Pemahaman Akuntansi berpengaruh positif dan signifikan terhadap Kepatuhan Pajak. Berdasarkan hasil bootstrapping path coefficient pada SmartPLS 2.0 M3 pada tabel 3 dapat dilihat bahwa variabel Pemahaman Akuntansi memiliki nilai t-statistik di atas 1,6683 ini dapat disimpulkan bahwa Pemahaman Akuntansi memiliki pengaruh yang signifikan terhadap Kepatuhan Pajak karena memiliki nilai koefisien parameter sebesar 0,662969 dengan nilai t-statistik yang sangat dominan yaitu $6,782921>1,6683$. Nilai tersebut memberi arti bahwa terdapat pengaruh signifikan pada tingkat $5 \%$ dengan nilai t-hitung $>$ dari t-tabel. Hal ini mengindikasikan terdapat pengaruh postif signifikan pada Pemahaman Akuntansi terhadap Kepatuhan Pajak. Sehingga dengan demikian maka hipotesis pertama diterima.

\section{Hipotesis kedua}

Variabel Moral berpengaruh positif dan signifikan terhadap Pemahaman Akuntansi. Berdasarkan hasil bootstrapping path coefficient pada SmartPLS 2.0 M3 pada tabel 3 dapat dilihat bahwa variabel Moral memiliki nilai t-statistik di atas 1,6683. Variabel Moral memiliki nilai koefisien parameter sebesar 0,412159 dengan nilai t-statistik 4,555642 >1,6683. Nilai tersebut memberi arti bahwa variabel Moral memiliki pengaruh positif yang signifikan pada tingkat $5 \%$ dengan nilai t-hitung $>$ dari t-tabel. Indikasi ini menjelaskan bahwa terdapat pengaruh postif dan signifikan pada Moral terhadap Pemahaman Akuntansi karena koefisien parameter bernilai positif sebesar 0,412159 dan t-statistik 4,555642 > 1,6683. Sehingga dengan demikian dapat dikatakan hipotesis kedua diterima.

Variabel sikap berpengaruh positif dan signifikan terhadap Pemahaman Akuntansi. Berdasarkan hasil bootstrapping path coefficient pada SmartPLS 2.0 M3 pada Tabel 3. dapat dilihat bahwa variabel Sikap memiliki nilai t-statistik di bawah 1,6683. Variabel Sikap memiliki nilai koefisien parameter sebesar -0,037714 dengan nilai t-statistik $0,306161<1,6683$. Nilai tersebut memberi arti bahwa variabel Sikap memiliki pengaruh negatif tidak signifikan pada tingkat $5 \%$ dengan nilai t-hitung $<$ dari t-tabel. Indikasi ini menjelaskan bahwa terdapat pengaruh negatif dan tidak signifikan pada Sikap terhadap Pemahaman Akuntansi karena koefisien parameter bernilai negatif sebesar $-0,037714$ dan T-statistik 0,306161<1,6683. Sehingga dengan demikian dapat dikatakan hipotesis kedua ditolak. Variabel Norma Subjektif berpengaruh positif dan signifikan terhadap Pemahaman Akuntansi. Berdasarkan hasil bootstrapping path coefficient pada SmartPLS $2.0 \mathrm{M} 3$ pada tabel 3. dapat dilihat bahwa variabel Norma Subjektif memiliki nilai t-statistik di bawah 1,6683. Variabel Norma Subjektif memiliki nilai t-statistik di bawah 1,6683. Variabel Norma Subjektif memiliki nilai koefisien parameter sebesar 0,151362 dengan nilai tstatistik $1,446787<1,6683$. Nilai tersebut memberi arti bahwa variabel Norma 
Subjektif memiliki pengaruh positif tidak signifikan pada tingkat 5\% dengan nilai thitung $<$ dari t-tabel. Indikasi ini menjelaskan bahwa terdapat pengaruh positif dan tidak signifikan pada Norma Subjektif terhadap Pemahaman Akuntansi karena koefisien parameter bernilai positif sebesar 0,151362 dengan nilai t-statistik $1,446787<1,6683$. Sehingga dengan demikian dapat dikatakan hipotesis kedua ditolak.

\section{Hipotesis ketiga}

Variabel-variabel Moral, Sikap dan Norma Subjektif berpengaruh positif dan signifikan terhadap Kepatuhan Pajak melalui variabel Pemahaman Akuntansi. Berdasarkan hasil bootstrapping path coefficient pada SmartPLS 2.0 M3 pada tabel 5.22 dengan perhitungan pengaruh total effect dan pengaruh tidak langsung (indirect effect). Dapat dilihat bahwa pengaruh variabel Moral terhadap variabel Kepatuhan Pajak melalui variabel Pemahaman Akuntansi memiliki nilai t-statistik di atas 1,6683 dengan pengaruh total effect sebesar 1,075128 dengan t-statistik 11,338563 > T-tabel 1,6683 (significance level $=5 \%$ ). Pengaruh tidak langsung (indirect effect) sebesar 0,273249 dengan T-statistik 30,900560 > T-tabel 1,6683 (significance level $=5 \%$ ). Berdasarkan analisa yang dilakukan maka dapat disimpulkan bahwa Moral memiliki pengaruh yang positif dan signifikan terhadap Kepatuhan Pajak melalui Pemahaman Akuntansi. Sehingga dengan demikian maka pengaruh variabel Moral terhadap variabel Kepatuhan Pajak melalui variabel Pemahaman Akuntansi positif dan signifikan sehingga hipotesis ketiga diterima.

Dapat dilihat bahwa pengaruh variabel Sikap terhadap variabel Kepatuhan Pajak melalui variabel Pemahaman Akuntansi memiliki nilai t-statistik di atas 1,6683 dengan pengaruh total effect sebesar 0,625255 dengan t-statistik 7,089082 > T-tabel 1,6683 (significance level $=5 \%$ ). Pengaruh tidak langsung (indirect effect) sebesar -0,025003 dengan T-statistik 2,076666 > t-tabel 1,6683 (significance level $=$ $5 \%$ ). Berdasarkan analisa yang dilakukan maka dapat disimpulkan bahwa Sikap memiliki pengaruh negatif dan signifikan terhadap Kepatuhan Pajak melalui Pemahaman Akuntansi. Sehingga dengan demikian maka pengaruh variabel Sikap terhadap variabel Kepatuhan Pajak melalui variabel Pemahaman Akuntansi negatif dan signifikan sehingga hipotesis ketiga ditolak.

Dapat dilihat bahwa pengaruh variabel Norma Subjektif terhadap variabel Kepatuhan Pajak melalui variabel Pemahaman Akuntansi memiliki nilai T-statistik di atas 1,6683 dengan pengaruh total effect sebesar 8,229708 dengan T-statistik $8,229708>$ T-tabel 1,6683 (significance level $=5 \%$ ). Pengaruh tidak langsung (indirect effect) sebesar 0,100348 dengan T-statistik 9,813442 > T-tabel 1,6683 (significance level $=5 \%$ ). Berdasarkan analisa yang dilakukan maka dapat disimpulkan bahwa Norma Subjektif memiliki pengaruh positif dan signifikan terhadap Kepatuhan Pajak melalui Pemahaman Akuntansi. Sehingga dengan demikian maka pengaruh variabel Norma Subjektif terhadap variabel Kepatuhan Pajak melalui variabel Pemahaman Akuntansi positif dan signifikan sehingga hipotesis ketiga diterima.

Dari hasil di atas dapat disimpulkan bahwa (1) berdasarkan hasil bootstrapping path coefficient mengindikasikan bahwa terdapat pengaruh postif tetapi tidak signifikan pada Moral, Sikap, Norma Subjektif terhadap Kepatuhan Pajak. (2) Berdasarkan hasil bootstrapping path coefficient mengindikasikan terdapat pengaruh postif signifikan pada Pemahaman Akuntansi terhadap Kepatuhan 
Pajak. (3) Berdasarkan hasil bootstrapping path coefficient bahwa terdapat pengaruh postif dan signifikan pada Moral terhadap Pemahaman Akuntansi. (4) Berdasarkan hasil bootstrapping path coefficient bahwa terdapat pengaruh negatif dan tidak signifikan pada Sikap terhadap Pemahaman Akuntansi. (5) Berdasarkan hasil bootstrapping path coefficient dengan perhitungan pengaruh total effect dan pengaruh tidak langsung (indirect effect) dan analisa yang dilakukan maka dapat disimpulkan bahwa Moral memiliki pengaruh yang positif dan signifikan terhadap Kepatuhan Pajak melalui Pemahaman Akuntansi. (6) Pengaruh variabel Sikap terhadap variabel Kepatuhan Pajak melalui variabel Pemahaman Akuntansi dengan pengaruh total effect dan pengaruh tidak langsung (indirect effect), berdasarkan analisa yang dilakukan maka dapat disimpulkan bahwa Sikap memiliki pengaruh negatif dan signifikan terhadap Kepatuhan Pajak melalui Pemahaman Akuntansi. (7) Pengaruh variabel Norma Subjektif terhadap variabel Kepatuhan Pajak melalui variabel Pemahaman Akuntansi dengan pengaruh total effect dan pengaruh tidak langsung (indirect effect), berdasarkan analisa yang dilakukan maka dapat disimpulkan bahwa Norma Subjektif memiliki pengaruh positif dan signifikan terhadap Kepatuhan Pajak melalui Pemahaman Akuntansi.

Sehingga dapat disarankan peningkatan di dalam bimbingan dan penyuluhan serta sosialisasi tentang arti penting akuntansi dalam pelaporan perpajakan dan pelatihan-pelatihan akuntansi dikalangan wajib pajak khususnya pelaku UMKM sangat dibutuhkan untuk meningkatkan kepatuhan pajak sehingga penerimaan pajak dengan sendirinya meningkat dari tahun ketahun. Memberikan kemudahan di dalam praktek-praktek pelaporan pajak dengan akuntansi yang sederhana dan tidak sulit dalam pelaksanaannya kepada pelaku UMKM dan tidak terlepas dari pelayanan yang terbaik dari pihak/petugas pelayanan pajak akan menciptakan kesadaran dan ketaatan kepada kewajiban perpajakan dari setiap wajib pajak. Dengan demikian penerimaan negara dari sektor pajak yang bersumber dari UMKM akan terealisasi dan meningkat.

\section{Daftar pustaka}

Bobek, D. D., Hageman, A. M., \& Kelliher, C. F. (2013). Analyzing the Role of Social Norms in Tax Compliance Behavior. Journal of Business Ethics, $115(3), 451-468$.

Cahyonowati, N. (2011). Model Moral Dan Kepatuhan Perpajakan: Wajib Pajak Orang Pribadi. Jurnal Akuntansi Dan Auditing Indonesia, 15(2), 161-177.

Horngren. (2006). Akuntansi (6th ed.). Jakarta: PT. Indeks Kelompok Gramedia.

Jatmiko, A. N. (2007). Pengaruh Sikap Wajib Pajak pada Pelaksanaan Sanksi Denda, Pelayanan Fiskus dan Kesadaran Perpajakan terhadap Kepatuhan Wajib Pajak (Studi Empiris terhadap Wajib Pajak Orang Pribadi di Kota Semarang). Universitas Diponegoro.

Nkwe, N. (2013). Tax Payers' Attitude and Compliance Behavior among Small Medium Enterprises (SMEs) in Botswana. Business and Management Horizons, 1(1), 113-137. 
Saepudin, A. (2012). Pengaruh Pemahaman Akuntansi Dan Ketentuan Perpajakan Serta Transparansi Dalam Pajak Terhadap Kepatuhan Wajib Pajak Badan. Retrieved from https://journal.unsil.ac.id/download.php?id=308.

Salisbury, W. D., Chin, W. W., Gopal, A., \& Newsted, P. R. (2002). Research Report: Better Theory Through Measurement-Developing a Scale to Capture Consensus on Appropriation. Information System Research, 13(1), 91-103.

Salman, K. R., \& Farid, M. (2008). Pengaruh Sikap dan Moral Wajib Pajak Pada Industri Perbankan di Surabaya. Journal of Economic, Business \& Accountancy.

Sarwono, J., \& Narimawati, U. (2015). Membuat skripsi, Tesis dan Disertasi dengan Partial Least Square SEM (PLS-SEM). Yogyakarta: Andi Offset.

Torgler, B. (2007). Tax Compliance and Tax Morale: A Theoretical and Empirical Analysis. Cheltenham, UK: Edward Elgar.

Tusubira, F. N., \& Nkote, I. N. (2013). Social Norms, Taxpayers' Morale and Tax Compliance: The Case of Small Business Enterprises in Uganda. Journal of Accounting, Taxation and Performance Evaluation, 2(1).

Tax-Compliance. (2016). Retrieved www.moneycontrol.com/glossary/taxes/tax-compliance_3114.html

from 